\title{
Germination ecology of native plant species for use in restoration and the urban landscape in Nova Scotia, Canada
}

\author{
Amy Heim, Ayako Nagase, Jeremy Lundholm, and Carly Wrathall
}

In Nova Scotia, Canada, demand is high for native species for ecological restoration and use in the urban environment. The region has few native plant suppliers, however, which forces groups to seek resources outside their region or to grow their own vegetation. Collecting, storing, and germinating seeds facilitate access to large quantities of viable seeds for use in projects. We conducted 4 germination trials on 21 species native to Atlantic Canada. We examined germination response to various treatments including storage method (freshwater, dry, seeds, whole berries) and temperature $\left.\left(4^{\circ} \mathrm{C}\left[39.2^{\circ} \mathrm{F}\right]\right),-20^{\circ} \mathrm{C}\left[-4^{\circ} \mathrm{F}\right]\right)$, as well as germination irrigation treatments (saltwater, freshwater). Overall, we found that species preferred treatments that reflected their natural environment. Therefore, for Atlantic Canada, we recommend that species found in wet habitats should be stored in freshwater and species found in dry habitats should be stored dry, both conditions at $4{ }^{\circ} \mathrm{C}$ $\left(39.2^{\circ} \mathrm{F}\right)$.

Heim A, Nagase A, Lundholm J, Wrathall C. 2018. Germination ecology of native plant species for use in restoration and the urban landscape in Nova Scotia, Canada. Native Plants Journal 19(3):201-215.

KEY WORDS

CONVERSIONS

$\left({ }^{\circ} \mathrm{C} \times 1.8\right)+32={ }^{\circ} \mathrm{F}$

$\mathrm{mm} \times 0.04=$ in

$\mathrm{km} \times 0.62=\mathrm{mi}$ seed storage, saltwater, propagation, temperature

\section{NOMENCLATURE}

Kartesz and Meacham (1999)

This open access article is distributed under the terms of the CC-BY-NC-ND license (http:// creativecommons.org/licenses/byncnd/4.0) and is freely available online at: http://npj.uwpress.org. 
$\mathrm{I}$ nterest in using native plant species is increasing for landscaping, private gardens, and ecological restoration projects. Many landscape architects now consider plant conservation and climate adaptations when choosing prospective vegetation (Brzuszek and others 2007), and ecological restoration projects generally require native species when planting is suggested. The Atlantic provinces of Canada (New Brunswick, Newfoundland and Labrador, Nova Scotia, and Prince Edward Island) are home to more than 1500 species of native vascular plants (ACCDC 2017). The region has few native plant suppliers, however, which forces practitioners to seek resources outside their region or to grow their own plants. In Nova Scotia, demand is for native species for salt marsh restoration and use in the urban environment (for example, green roofs). The types of plant species needed for salt marsh restoration include those commonly found across a range of tidal regimes from low salt marsh to brackish systems (Porter and others 2015) including dominant grasses (Spartina spp. [Poaceae]). For use in the urban environment, roadside and coastal plants (for example, Festuca rubra L. [Poaceae]) are a viable option as they can survive harsh environments exposed to rapid drainage, strong winds, and salt spray (Nellis 1994). Coastal plants have already been successfully established on green roofs in the province (MacIvor and Lundholm 2011; Heim and others 2016). To better promote the use of native plants in Atlantic Canada we must first understand their germination ecology.

Collecting, storing, and germinating seeds facilitate access to large quantities of viable seeds for use in projects related to ecological restoration and green infrastructure. How these seeds are stored has the potential to affect germination rates, and different plant species require specific storage and preparation methods. For example, wet or dry stratification of seeds has been extensively studied in Spartina spp., showing that wet stratification enhances germination of these species (Callaway and Josselyn 1992; Bruno 2000; Chung and others 2004). As Spartina spp. grow primarily in salt marshes, this storage method reflects what seeds would be exposed to in the natural environment. Applying this reasoning to other regional native species that have not been studied from the perspective of propagation will provide us with a stronger understanding of germination requirements for individual species, allowing growers to increase the quantity of species used in restoration and green infrastructure.

To understand the germination ecology of species native to Nova Scotia, we have compiled 4 germination trials. These trials provide information on seed storage and treatment methods for 21 species native to Atlantic Canada. Some of the species examined have been extensively studied in other geographic locations (for example, Spartina spp.) (Callaway and Josselyn 1992; Bruno 2000; Chung and others 2004). Given that plant traits can be geographically variable (Mobberley 1956; Fang and others 2004), however, we wanted to specifically test seeds gathered from Nova Scotia.

\section{METHODS}

Between 2005 and 2017, 4 germination trials were conducted on 21 species native to Nova Scotia. These species were selected for their potential to survive on green roofs (species found on coastal barrens, roadsides, dunes) or because they are used in salt marsh restoration (species found on salt marshes). The majority of seeds were collected around Halifax, Nova Scotia, which has an average yearly temperature of $7.7^{\circ} \mathrm{C}$ and an average yearly precipitation of $1468.1 \mathrm{~mm}$ (Government Canada 2018). All germination trials were conducted in growth chambers at Saint Mary's University, located in Halifax (44.63222 N, 63.58139 W) (Figure 1B, 1C). For each species, all berries and (or) seeds were collected by hand from the same grouping of plants and placed in one collection container. Germination trials examined germination rates for different pre-storage, temperature, and irrigation treatments (Table 1). Each trial ended after 2 wk with no germination.

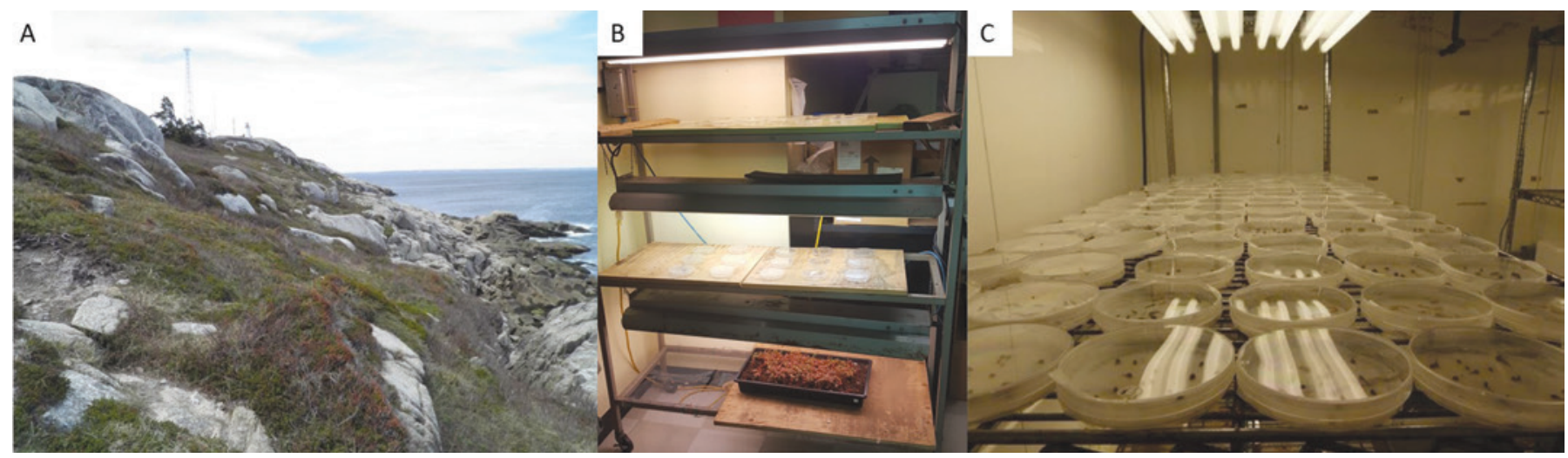

Figure 1. One of the coastal barren seed collection sites (Chubucto Head) (A), the growth chamber used in Trials 1 and 4 (B), and the growth 
Overview of the 4 germination trials.

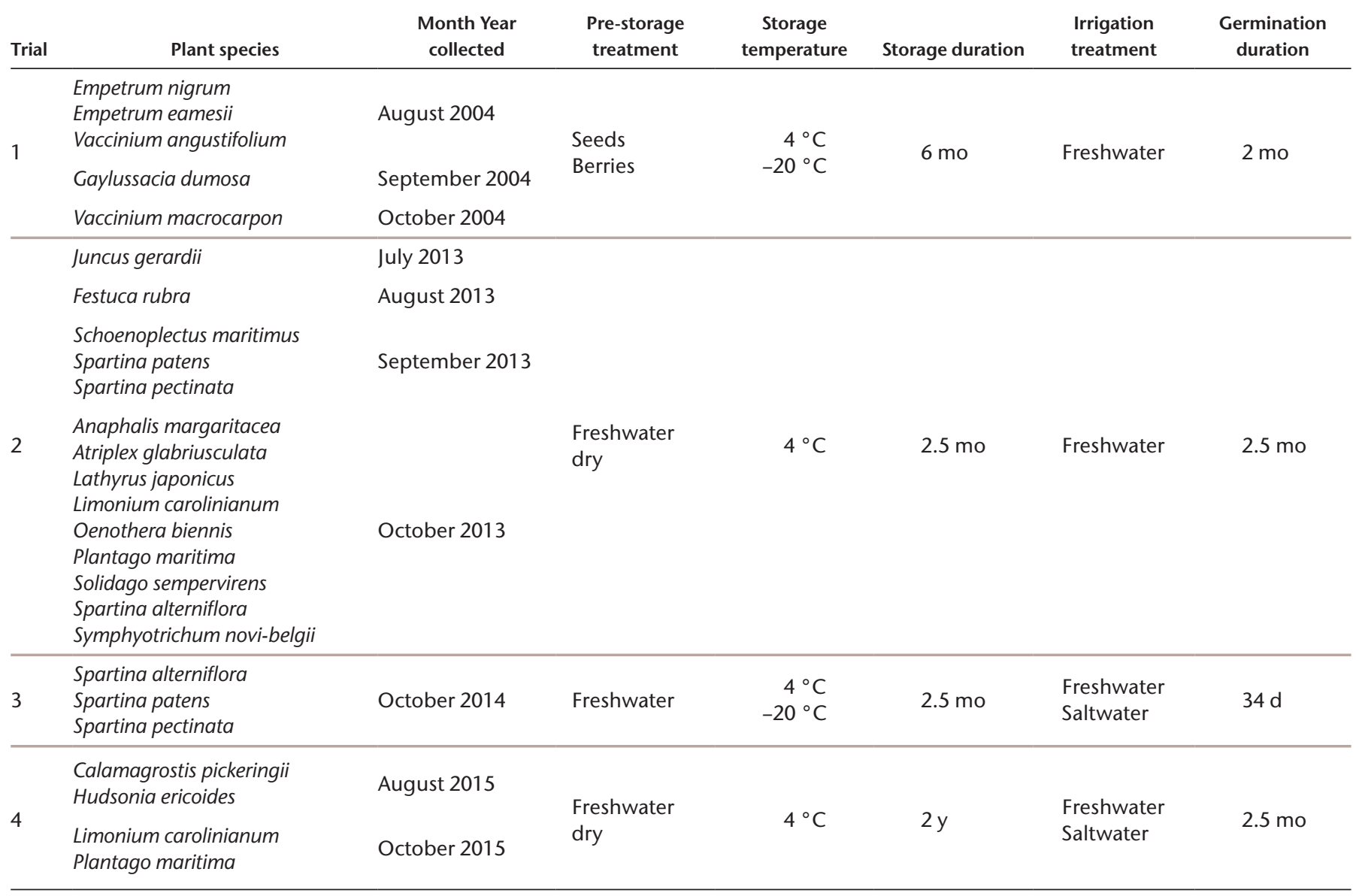

Trial 1: Storage at $4{ }^{\circ} \mathrm{C}$ vs. $-20^{\circ} \mathrm{C}$ and Seeds vs. Berries

In 2004, berries from Empetrum nigrum L. (black crowberry [Ericaceae]), Empetrum eamesii Fernald \& Wiegand (purple crowberry [Ericaceae; some sources place Empetrum in Empetraceae]), Vaccinium angustifolium Aiton (lowbush blueberry [Ericaceae]) (Figure 2), Gaylussacia dumosa Fern. (dwarf huckleberry [Ericaceae]), and Vaccinium macrocarpon Aiton (cranberry [Ericaceae]) (Figure 3) were collected from Chubucto Head, a coastal barren site located $16 \mathrm{~km}$ from Halifax, Nova Scotia (see Table 1; Figure 1A). Although it is difficult to differentiate individual plants in these clonal shrubs, berries from approximately 25 to 50 plants were collected for each species.

Immediately after collection, berries were separated into different storage treatments: dry storage at $4{ }^{\circ} \mathrm{C}$ for individual seeds (seeds removed from fruit with tweezers) or whole berries, and dry storage at $-20{ }^{\circ} \mathrm{C}$ for individual seeds or whole berries ( $V$. macrocarpon and G. dumosa were stored at only $4{ }^{\circ} \mathrm{C}$ ). Germination trials began on 11 May 2005 and ended on 16 August 2005. Seeds and (or) berries were germinated at room temperature $\left(17-20^{\circ} \mathrm{C}\right)$ under a growth light, in plastic

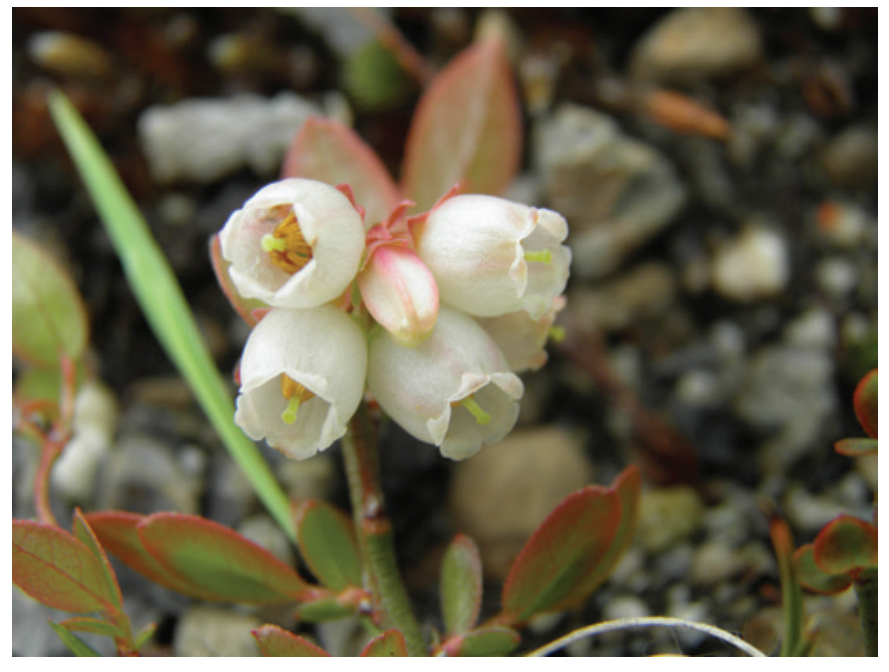

Figure 2. Vaccinium angustifolium (Green roof, Saint Mary's University). Photo by Amy Heim

plant cells ( 1 per cell) that contained soil that was kept moist throughout the entire trial. The number of seeds and (or) berries for each replicate was chosen based on the average number 


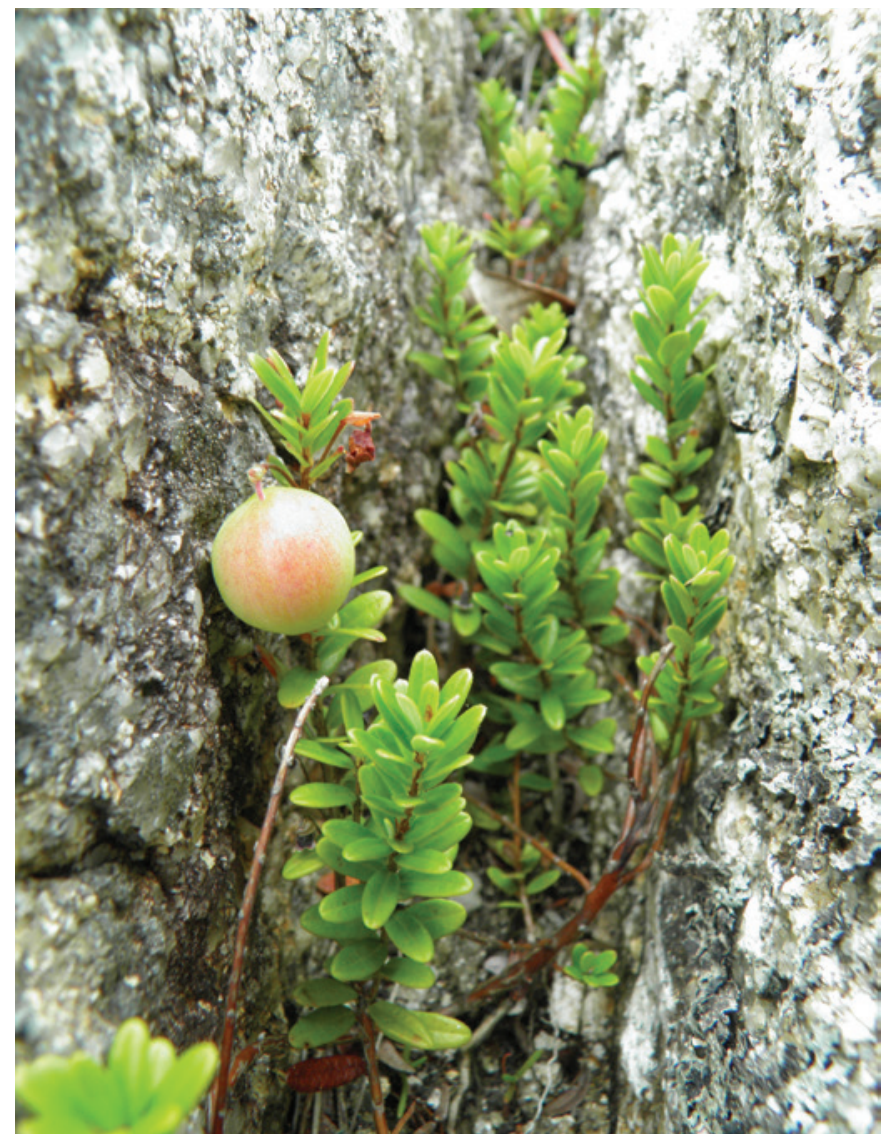

Figure 3. Vaccinium macrocarpon (Duncan's Cove Nature Reserve, Nova Scotia). Photo by Amy Heim

of seeds found in a typical berry for that species (see Appendix Table A.2).

\section{Trial 2: Wet vs. Dry Storage}

In 2013, seeds were collected from the Chubucto head coastal barren (Oenothera biennis L. [common evening primrose; Onagraceae], Plantago maritima L. [goose tongue; Plantaginaceae]) (Figure 4); the green roof at Saint Mary's University (located in Halifax) (Anaphalis margaritacea (L.) Benth. [western pearly everlasting; Asteraceae], Festuca rubra L. [red fescue; Poaceae], Symphyotrichum novi-belgii L. [New York aster; Asteraceae]); and the Conrad's Beach salt marsh (17 km from Halifax) (Atriplex glabriusculata Edmondston [Scotland orache; Chenopodiaceae], Juncus gerardii Loisel. [saltmeadow rush; Juncaceae], Lathyrus japonicus Willd. [beach pea; Fabaceae] (Figure 5), Limonium carolinianum (Walter) Britton [lavender thrift; Plumbaginaceae], Schoenoplectus maritimus (L.) Nels. [cosmopolitan bulrush; Cyperaceae], Solidago sempervirens L. [seaside goldenrod; Asteraceae], Spartina alterniflora Loisel. [smooth cordgrass; Poaceae], Spartina patens (Aiton) Muhl. [saltmeadow cordgrass], Spartina pectinata Bosc ex Link [prairie cordgrass]) (see Table 1). For the forbs, seeds were collected from 20 to 40 individual plants per species. For grasses, seeds were collected

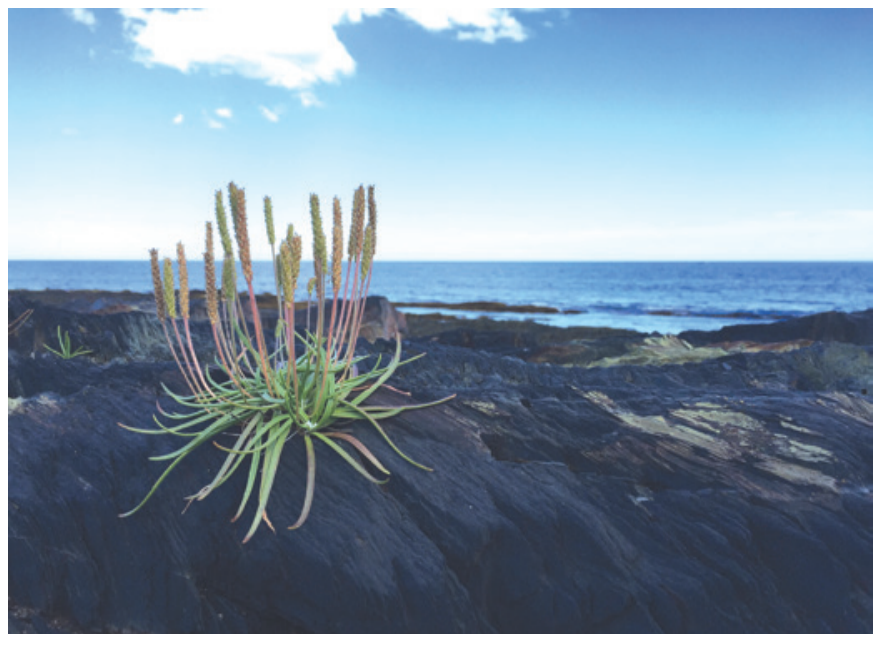

Figure 4. Plantago maritima (Crystal Crescent Provincial Park, Nova Scotia). Photo by Jeremy Lundholm

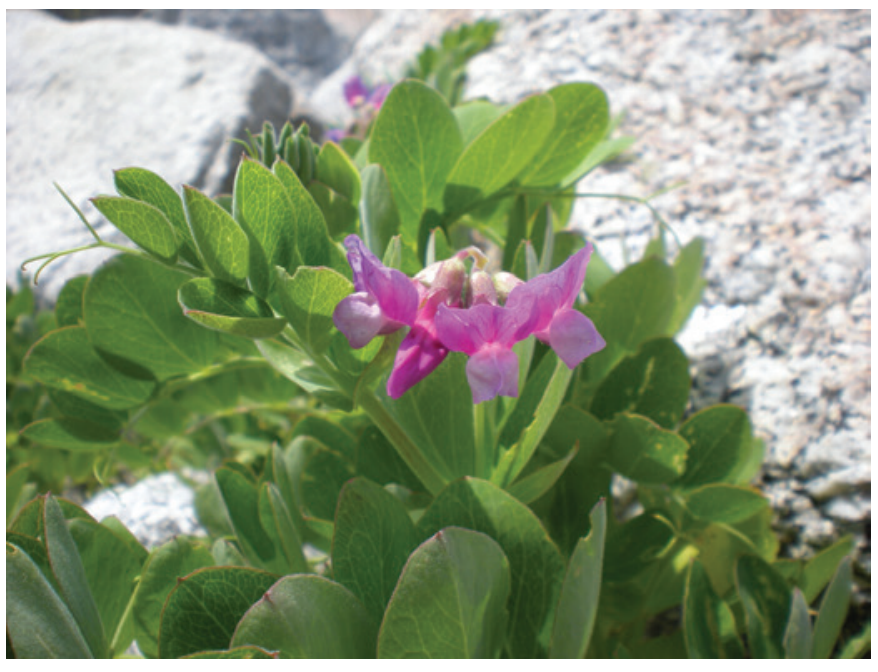

Figure 5. Lathyrus japonicus (Crystal Crescent Provincial Park, Nova Scotia). Photo by Jeremy Lundholm

Once collected, seeds were stored dry at room temperature $\left(20^{\circ} \mathrm{C}\right)$ until the storage treatment began on 18 October 2013. This trial included 2 storage treatments: half the seeds for each species were stored dry at $4{ }^{\circ} \mathrm{C}$ in a moisture-free container. The second half of the seeds were placed in a sealable bag, moistened in tap water, and stored at $4{ }^{\circ} \mathrm{C}$. From January 2014 until May 2014, seeds were germinated at room temperature $\left(20^{\circ} \mathrm{C}\right)$ under a full-spectrum fluorescent growth light in covered Petri plates containing moistened filter paper (see Figure 1C, Figure 6). During the trials, treatments were continually moistened with deionized water $(\sim 2 \mathrm{ml}$ with each irrigation) to ensure water availability for the seeds.

Trial 3: Storage at $4{ }^{\circ} \mathrm{C}$ vs. $-20^{\circ} \mathrm{C}$ and Freshwater vs. Saltwater Irrigation

In October 2014, seeds from S. alterniflora, S. patens, and S. pectinata were collected from 4 salt marsh sites: Conrad's 


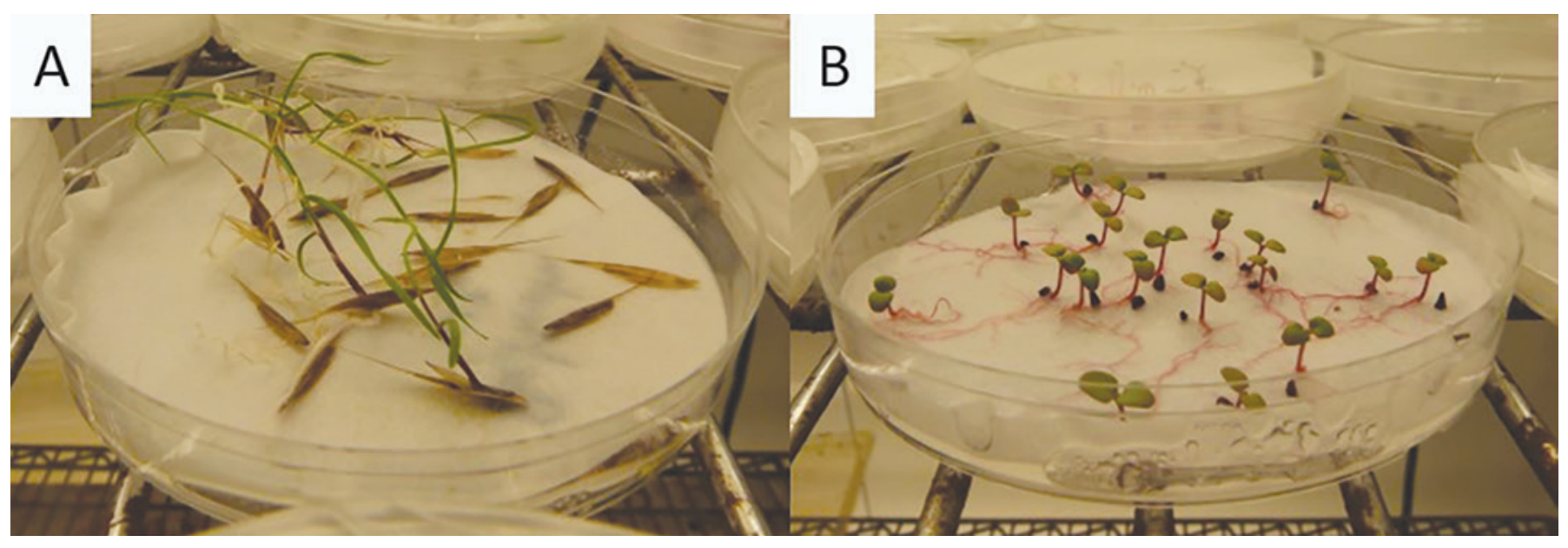

Figure 6. Spartina pectinata (A) and Oenothera biennis (B) germinating in the wet treatment during the 2013 trial. Photo by Amy Heim

Beach and Rainbow Haven (13 km from Halifax), which are located on the Atlantic Coast of Nova Scotia, and the Windsor (57 km from Halifax) and Cogmagun salt marsh (60 km from Halifax), which are located on the Bay of Fundy Coast of Nova Scotia (see Table 1). Compared to Halifax, the Bay of Fundy region has an average yearly temperature of $7.4^{\circ} \mathrm{C}$ and an average yearly precipitation of $1309.6 \mathrm{~mm}$. Seeds were collected from 20 to 40 individuals per species. Immediately after collection, seeds were washed in tap water and sprayed with a 5\% concentration of Safer's Defender Garden fungicide to reduce mold (Fang and others 2004; Li and others 2010). Seeds were stored damp $(\sim 10 \mathrm{ml}$ of water $)$ at $4{ }^{\circ} \mathrm{C}$ for $4 \mathrm{~d}$ and then stored damp at $4{ }^{\circ} \mathrm{C}$ for $2.5 \mathrm{mo}$. From January to February 2015 , seeds were germinated at room temperature $\left(20^{\circ} \mathrm{C}\right)$ under a full-spectrum fluorescent growth light in covered Petri plates containing filter paper (see Figure 1C). During germination, half the seeds were irrigated with freshwater $(\sim 2 \mathrm{ml}$ with each irrigation) and the other half were irrigated with saltwater $(\sim 2 \mathrm{ml}$ with each irrigation, salt and tap water $[1 \% \mathrm{NaCl}])$.

\section{Trial 4: Freshwater vs. Dry Storage and Saltwater vs. Freshwater Irrigation}

In 2015 seeds from P. maritima, Calamagrostis pickeringii A. Gray (Pickering's reedgrass [Poaceae]), and Hudsonia ericoides L. (pine barren goldenheather [Cistaceae]) (Figure 7) were collected from Chubucto Head, and seeds from L. carolinianum were collected from Conrad's Beach (see Table 1). Seeds were collected from 15 to 20 individuals for Hudsonia and 30 to 50 individuals for the other species. Half of these seeds were stored dry, and half were stored wet (see Trial 2). From September to October 2017, seeds were germinated at room temperature $\left(20^{\circ} \mathrm{C}\right)$ under a full-spectrum fluorescent growth light in covered Petri plates containing filter paper (see Figure 1B). During germination, P. maritima, C. pickeringii, and $H$. ericoides seeds were irrigated with freshwater $(\sim 2 \mathrm{ml}$ with each irrigation). For P. maritima, half the seeds were also irrigated

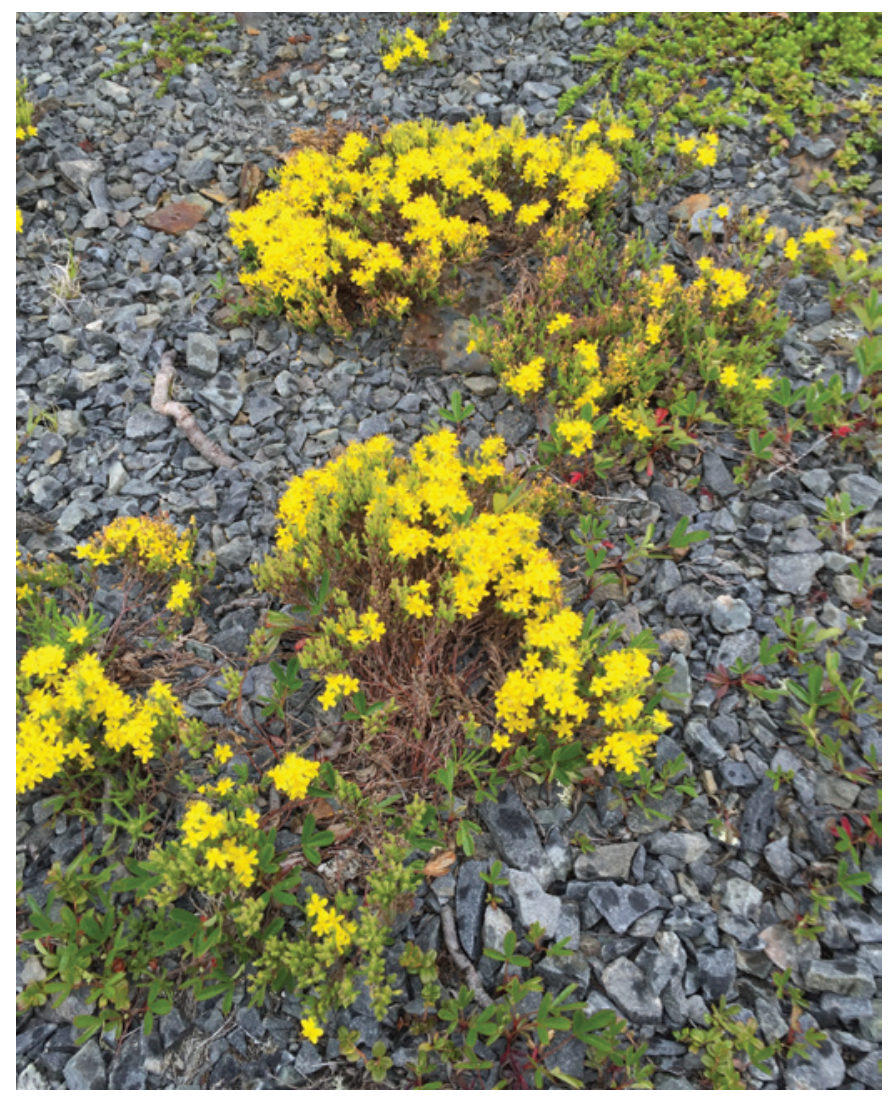

Figure 7. Hudsonia ericoides (Duncan's Cove Nature Reserve, Nova Scotia). Photo by Jeremy Lundholm

once at the beginning of the germination period with saltwater (5 ml [0.17 fl oz]) (3\% Reef Crystals Reef Salt). Saltwater was added only once, as seeds were not rinsed between irrigation and we wanted to avoid a build-up of salt.

\section{Statistical Analysis}

A one-way ANOVA was used to compare treatments using 2 storage methods: moist vs. dry stratification. A twoway ANOVA and Tukey post hoc test were used to examine 
treatments using more than 2 methods: dry stratification at $4{ }^{\circ} \mathrm{C}$ vs. $-20{ }^{\circ} \mathrm{C}$ for whole berry vs. seeds; stratification with freshwater vs. saltwater during storage at $4{ }^{\circ} \mathrm{C}$ and $-20^{\circ} \mathrm{C}$; and freshwater vs. saltwater irrigation during germination with seeds that were stored wet and dry. For each data set, a ShapiroWilk test was used to test for normality and transformed if data were not normally distributed (see Appendix Tables) (R Project for Statistical Computing version 3.1.1; Warton and Hui 2011).

\section{TABLE 2}

Average germination rate (\%) $\pm S E$ and number of seeds per replicate $(x / x)$ for species in Trial 1 .

\begin{tabular}{lcccc}
$\begin{array}{l}\text { Storage temperature } \\
\text { Storage treatment }\end{array}$ & $\begin{array}{c}4{ }^{\circ} \mathrm{C} \\
\text { Seeds }\end{array}$ & $\begin{array}{c}20^{\circ} \mathrm{C} \\
\text { Seeds }\end{array}$ & $\begin{array}{c}4^{\circ} \mathrm{C} \\
\text { Berry }\end{array}$ & $\begin{array}{c}20^{\circ} \mathrm{C} \\
\text { Berry }\end{array}$ \\
\hline \begin{tabular}{l} 
Empetrum nigrum $(x / 8)$ \\
\hline $\begin{array}{l}\text { Vaccinium angustifolium } \\
(\mathrm{x} / 41)\end{array}$
\end{tabular} & $14.8 \pm 2.2$ & 0 & 0 & 0 \\
\hline \begin{tabular}{l} 
Empetrum eamesii $(\mathrm{x} / 8)$ \\
\hline Gaylussacia dumosa $(\mathrm{x} / 10)$
\end{tabular} & 0 & $0.1 \pm .06$ & 0 & 0 \\
\hline $\begin{array}{l}\text { Vaccinium macrocarpon } \\
(\mathrm{x} / 16)\end{array}$ & $65.6 \pm 4.8$ & $\mathrm{NA}$ & $2.8 \pm 2.8$ & $\mathrm{NA}$
\end{tabular}

Notes: Replicates for Gaylussacia dumosa treatments were $n=9$, and replicates for all other treatments were $n=18$. SE, standard error.

\section{RESULTS}

Trial 1: Storage at $4{ }^{\circ} \mathrm{C}$ vs. $-20^{\circ} \mathrm{C}$ and Seeds vs. Berries

No germination was observed for G. dumosa, V. angustifolium germinated only in the seeds at $4{ }^{\circ} \mathrm{C}$ treatment, and $E$. rubrum germinated only in the seeds at $-20^{\circ} \mathrm{C}$ treatment. Empetrum nigrum germinated only when planted as seeds, with the highest germination observed for the seeds at $4{ }^{\circ} \mathrm{C}$ treatment. For $V$. macrocarpon, the highest germination occurred when planted as seeds (Table 2). Although details were not recorded, authors also observed that the seeds of $V$. angustifolium germinated en masse 2 mo into the experiment, whereas the seedlings of the V. macrocarpon and the Empetrum spp. germinated within $2 \mathrm{wk}$.

\section{Trial 2: Wet vs. Dry Storage}

No germination was observed for C. pickeringii or J. gerar$d i i$, therefore, these species were excluded from the statistical analysis. The cold, moist stratification treatment significantly increased the germination rate for 8 species (A. glabriusculata, O. biennis, P. maritima, S. sempervivum, S. alterniflora, S. patens, S. pectinata, and S. novi-belgii) and decreased the number of days until germination for 9 species (A. glabriusculata, F. rubra, L. carolinianum, S. sempervivum, S. alterniflora, S. patens, S. pectinata, and S. novi-belgii). Only 1 species, O. biennis, germinated significantly earlier in the dry treatment (Table 3 ).

TABLE 3

Average germination rate and average number of days until germination \pm SE for species in Trial 2.

\begin{tabular}{|c|c|c|c|c|}
\hline \multirow{2}{*}{$\begin{array}{l}\text { Species } \\
\text { Trial } 2\end{array}$} & \multicolumn{2}{|c|}{ Germination rate (\%) } & \multicolumn{2}{|c|}{ Average days until germination } \\
\hline & Wet $(x / 20)$ & Dry $(x / 20)$ & Wet & Dry \\
\hline Anaphalis margaritacea & $13.3 \pm 6.0$ & $3.3 \pm 3.3$ & $12.2 \pm 0.4$ & $14.0 \pm \mathrm{NA}$ \\
\hline Atriplex glabrisculata & $96.7 \pm 3.3^{*}$ & $70.0 \pm 7.6^{*}$ & $4.1 \pm 0.2^{*}$ & $27.6 \pm 3.7^{*}$ \\
\hline Festuca rubra & $58.3 \pm 3.3$ & $53.3 \pm 1.7$ & $6.4 \pm 0.3^{*}$ & $10.0 \pm 0.3^{*}$ \\
\hline Lathyrus japonicus & $0.0 \pm 0.0$ & $1.7 \pm 1.7$ & NA & $6 \pm N A$ \\
\hline Limonium carolinianum & $65.0 \pm 7.6$ & $50.0 \pm 2.9$ & $6.4 \pm 0.6^{*}$ & $21.6 \pm 0.7^{*}$ \\
\hline Oenothera biennis & $95.0 \pm 2.9^{*}$ & $15.0 \pm 2.9^{*}$ & $3.3 \pm 1.0^{*}$ & $9.5 \pm 3.6^{*}$ \\
\hline Plantago maritima & $95.0 \pm 2.9^{*}$ & $13.3 \pm 1.7^{*}$ & $3.4 \pm 0.1$ & $10.9 \pm 4.9$ \\
\hline Schoenoplectus maritimus & $10.0 \pm 7.6$ & $10.0 \pm 5.8$ & $7.9 \pm 2.4$ & $15.9 \pm 5.5$ \\
\hline Solidago sempervirens & $85.0 \pm 7.6$ & $36.7 \pm 7.3^{*}$ & $4.3 \pm 0.1^{*}$ & $10.5 \pm 1.1$ * \\
\hline Spartina alterniflora & $35.0 \pm 5.8^{*}$ & $18.3 \pm 1.7^{*}$ & $19.2 \pm 3.0^{*}$ & $31.5 \pm 1.7^{*}$ \\
\hline Spartina patens & $28.3 \pm 3.3^{*}$ & $6.7 \pm 1.7^{*}$ & $6.3 \pm 0.6^{*}$ & $47.0 \pm 7.5^{*}$ \\
\hline Spartina pectinata & $40.0 \pm 8.7^{*}$ & $6.7 \pm 1.7^{*}$ & $6.3 \pm 0.4^{*}$ & $44.2 \pm 5.1^{*}$ \\
\hline Symphyotrichum novi-belgii & $51.7 \pm 9.3$ & $38.3 \pm 9.3$ & $4.9 \pm 0.3^{*}$ & $19.0 \pm 3.3^{*}$ \\
\hline
\end{tabular}

Notes: Each species was stored at $4{ }^{\circ} \mathrm{C}$ and had a freshwater and a dry storage treatment. Trial 2 had 3 replicates with 20 seeds per replicate. For each species and category, an * indicates significant difference between treatments $(P<0.05)$. Only 1 replicate of Lathyrus japonicus germinated, and only 1 replicate of Anaphalis margaritacea germinated in the dry treatment, 
Trial 3: Storage at $4{ }^{\circ} \mathrm{C}$ vs. $-20^{\circ} \mathrm{C}$ and Freshwater vs. Saltwater Irrigation

Compared to all other treatments, both S. pectinata and $S$. patens had a significantly higher germination rate in the freshwater at $4{ }^{\circ} \mathrm{C}$ treatment. For S. alterniflora, no seeds germinated in the freshwater at $-20^{\circ} \mathrm{C}$ treatment, and only 1 replicate germinated in the saltwater at $-20^{\circ} \mathrm{C}$ treatment. Spartina alterniflora had a significantly higher germination rate when stored at $4{ }^{\circ} \mathrm{C}$, with no significant difference observed between freshwater and saltwater treatments. For all 3 species, the freshwater at $4{ }^{\circ} \mathrm{C}$ treatment resulted in the quickest germination time (Figure 8).

\section{Trial 4: Freshwater vs. Dry and Saltwater vs.}

\section{Freshwater}

For Trial 4, the dry storage/freshwater treatment of P. maritima had a significantly higher germination rate than all other treatments. Additionally, P. maritima germinated significantly faster in the wet storage/freshwater treatment than in the dry storage/saltwater treatment. Limonium carolinianum had a significantly greater germination rate in the dry treatment; however, it had a significantly shorter delay in germination in the wet treatment. No significant difference was observed for $H$. ericoides; 2 of the 3 wet treatments for $H$. ericoides did not germinate (Table 4).

\section{DISCUSSION}

Out of the 21 species examined, all but 6 had a treatment that resulted in a significant increase in germination and (or) a significant decrease in the number of days until germination. Out of the 6 species that did not vary significantly between treatments (C. pickeringii, G. dumosa, J. gerardii, A. margaritacea, L. japonicus, and S. maritimus), all had zero to low germination (between $0 \%$ and $>13.5 \%$ ). For those species with a preferred treatment, the methods used often reflected each species' natural environment. This trend is also reflected in the literature, with species from wet habitats responding positively to wet stratification (Fenner and Thompson 2005; Liu and others 2010; Baskin and Baskin 2014) and species from cold,
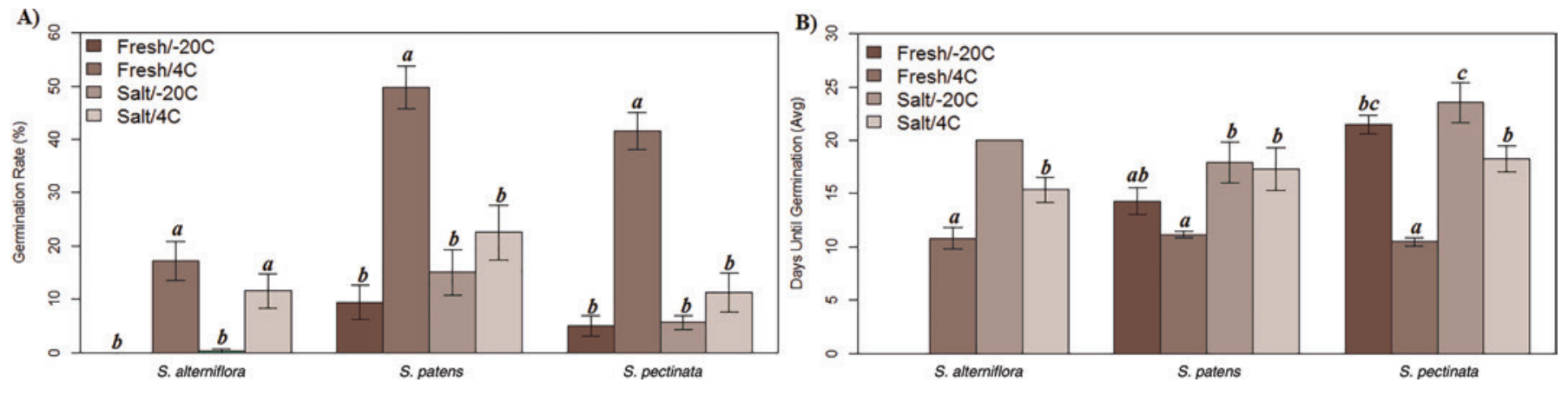

Figure 8. Average germination rate (A) and average number of days until germination (B) for Spartina alterniflora, S. patens, and S. pectinata when stored in freshwater (fresh) vs. saltwater (salt) at $4{ }^{\circ} \mathrm{C}$ vs. $-20^{\circ} \mathrm{C}$. Spartina alterniflora in the freshwater at $-20^{\circ} \mathrm{C}$ treatment did not germinate, and only 1 replicate germinated in the saltwater at $-20^{\circ} \mathrm{C}$ treatment. For each species, those bars that share a letter are not significantly different. Error bar indicates standard error.

TABLE 4

Trial 4: Freshwater vs. dry storage for Plantago maritima, Hudsonia ericoides, and Limonium carolinianum, and the use of saltwater vs. freshwater irrigation for Plantago maritima.

\begin{tabular}{|c|c|c|c|c|c|c|c|c|}
\hline \multirow{2}{*}{$\begin{array}{l}\text { Species } \\
\text { Storage }\end{array}$} & \multicolumn{4}{|c|}{ Germination rate (\%) } & \multicolumn{4}{|c|}{ Average days until germination } \\
\hline & \multicolumn{2}{|c|}{ Wet $(x / 50)$} & \multicolumn{2}{|c|}{$\operatorname{Dry}(x / 50)$} & \multicolumn{2}{|c|}{ Wet } & \multicolumn{2}{|c|}{ Dry } \\
\hline Hudsonia ericoides & \multicolumn{2}{|c|}{$2.0 \pm 2.0$} & \multicolumn{2}{|c|}{$11.8 \pm 2.2$} & \multicolumn{2}{|c|}{$4 \pm N A$} & \multicolumn{2}{|c|}{$5.9 \pm 0.9$} \\
\hline Storage & \multicolumn{2}{|c|}{ Dry } & \multicolumn{2}{|c|}{ Wet } & \multicolumn{2}{|c|}{ Dry } & \multicolumn{2}{|c|}{ Wet } \\
\hline Plantago maritima & $39.3 \pm 6.4^{*}$ & $6.0 \pm 6.0$ & $10.0 \pm 3.1$ & $9.3 \pm 2.4$ & $3.9 \pm 0.9$ & $7.5 \pm 1.2$ & $8.1 \pm 1.2$ & $13.4 \pm 4.5$ \\
\hline
\end{tabular}

Notes: This table shows average germination rate and the average number of days until germination \pm SE (standard error). The trial used 3 replicates with 50 seeds per replicate. An * indicates that the treatment performed significantly better $(P<0.05)$ than all other treatments. For Hudsonia ericoides, 2 of the 3 replicates in the wet treatment did not germinate. For P. maritima, the dry storage/freshwater treatment was significantly different from the wet storage/freshwater treatment. 
temperate climates preferring cold stratification (Baskin and Baskin 1995, 2014; Fenner and Thompson 2005; Liu and others 2010).

\section{Pre-Storage Treatment: Propagule Preparation}

For all berries studied (excluding G. dumosa, which did not germinate), seeds separated from the fruit had a significantly higher germination rate. This finding has been reported for Vaccinium spp. in the past (Vander Kloet and Hill 2000), but there has been comparatively little work done on Empetrum in North America. As berries are usually consumed by predators (Crossland and Vander Kloet 1996) or left to decompose, germination for these species may rely on particular light conditions (Pereira and Mourato 2012), but we did not test light vs. dark treatments in any of these trials. The lack of germination in G. dumosa could be caused by this species' association with fire and tendency toward vegetative reproduction (Coladonato 1992).

\section{Stratification Treatment: Moisture}

Over the course of 3 trials, 2 storage moisture regimes (freshwater/dry) were tested on 16 species. Out of these species, C. pickeringii and J. gerardii did not germinate, and A. margaritacea, L. japonicus, and S. maritimus had low germination. The lack of germination in C. pickeringii may have been attributable to the duration this species was stored ( $2 \mathrm{y})$, as this species has been successfully germinated after a 4-mo storage period (authors' personal observation). As for J. gerardii, the lack of germination may have been caused by damage to seeds during storage (for example, by fungal pathogens), as previous studies have successfully germinated this species (Charpentier and others 1998). Although our trial showed low germination of A. margaritacea and S. maritimus in both the wet and dry treatments, a previous study on $A$. margaritacea reported 47 to $64 \%$ germination in dry storage (Flessner and Trindle 2003), and for S. maritimus the use of cold, moist stratification improved germination (Clevering 1995). Additionally, germination rate in L. japonicus can increase after scarification (Chinnasamy and Bal 2003).

For the most part, species found in a wet environment responded positively to a wet storage treatment. For example, S. alterniflora, S. patens, S. pectinata, A. glabriusculata, and S. sempervirens all naturally occur in salt marshes (Roland and Zinck 1998), and the germination of these species significantly increased when they were stored wet. The trends observed for the Spartina spp. in our study are in line with previous germination experiments conducted with seeds from other regions (Callaway and Josselyn 1992; Bruno 2000; Chung and others 2004).

Previous research indicates that A. glabriusculata does not require a dormancy period; instead, germination is inhibited encompass the seeds of this species (Ignaciuk and Lee 1980). Therefore, storage preparation for this species should involve removing seeds from bracteoles and placing them in a moistened container at $4{ }^{\circ} \mathrm{C}$. Research is needed, however, to determine the longevity of A. glabriusculata seeds in storage.

For S. sempervirens, previous research has been conducted on a variety of this species, Solidago sempervirens L. var. mexicana L. Fernald (seaside goldenrod [Asteraceae]), which is found in S. sempervirens' southern range. Researchers were able to store $S$. sempervirens var. mexicana dry for 1 mo at $4{ }^{\circ} \mathrm{C}$ and had higher germination than recorded in our study (for both our wet and dry treatment) (Orava and Drake 1997). Based on our study, we recommend cold, moist stratification in freshwater at $4{ }^{\circ} \mathrm{C}$ for seeds gathered in Atlantic Canada.

Although no increase in germination rate was observed in any treatments for F. rubra, S. novi-belgii, or H. ericoides, these species did germinate faster in the freshwater storage treatment than in the dry treatment, an indication that cold, moist stratification reduces dormancy. Unlike the previous species, these 3 are not found in coastal wetlands but rather in relatively dry locations within coastal barrens or along the roadsides, which are naturally drier environments. For both $F$. rubra and S. novibelgii, previous studies also show that dry storage is acceptable, with cold-dry stratification the recommended method for germination (Kearns and Toole 1939; Moore and Anderson 2002).

And yet, O. biennis had significantly greater germination in the freshwater treatment even though it is not a wetland species. As this species is traditionally found along dry roadside environments, this preference could be attributable to $\mathrm{O}$. $b i$ ennis delaying germination until conditions are favorable for young seedlings. Previous research also indicates that cold-wet stratification results in high germination (95\%) for this species (Baskin and Baskin 1994).

Both P. maritima and L. carolinianum differed in their preferred moisture treatment between the 2013 and 2017 trials, with seeds from the 2013 trial preferring freshwater storage and seeds from the 2017 trial preferring dry storage. This difference is likely caused by the amount of time seeds were stored before germination, with seeds from Trial 2 stored for 2.5 mo and seeds for Trial 4 stored for $2 \mathrm{y}$. As the germination rate for these species decreased with time in storage, this observation may indicate that these species should be stored wet for short-term storage and dry for long-term storage. A 1972 study involving dry storage of $P$. maritima for several years reported a germination rate similar to our cold, moist stratification treatment (Arnold 1972). However, the difference observed between Trial 2 and Trial 4 may be because of the collection of seeds from different individuals. Future studies testing storage duration and preference should use seeds collected from the same individuals. 


\section{Storage Treatment: Temperature}

Storage temperature played a significant role in the germination of many of our species, with S. alterniflora, S. patens, S. pectinata, and E. nigrum preferring storage at $4{ }^{\circ} \mathrm{C}$, a trend consistent with the literature (Bell and Tallis 1973; Seneca 1974; Biber and others 2013a, 2013b). This cooler temperature preference is typical for species from this region and reflects natural winter storage conditions (Baskin and Baskin 2014). Only one species, E. eamesii, preferred a colder storage treatment with higher germination observed at $-20^{\circ} \mathrm{C}$. Unlike the other species exposed to this treatment, E. eamesii is commonly found on exposed rocky outcrops with little shelter from the surrounding environment (Dupuis 1988). This species' preference for $-20^{\circ} \mathrm{C}$ could reflect some adaptation toward a harsher environment or greater susceptibility to pathogens that can proliferate in unfrozen stratification conditions. A 1986 study also found variation in germination response to temperature in the same two Empetrum species examined in this study. Both E. eamesii and E. nigrum preferred germination at $25^{\circ} \mathrm{C}$; however, at reduced temperatures $\left(5^{\circ} \mathrm{C}\right.$ and $\left.10{ }^{\circ} \mathrm{C}\right)$ E. eamesii had a higher germination rate than did E. nigrum (Dupuis 1988).

\section{Irrigation Treatment}

For the 4 species with a saltwater irrigation treatment, $S$. patens, S. pectinata, and P. maritima preferred freshwater to saltwater. For S. alterniflora, saltwater did not have a significant impact on germination, and previous studies have also successfully germinated S. alterniflora when stored in saltwater (Mooring and others 1971). This pattern reflects where these species naturally occur in the salt marsh, with $S$. patens, P. maritima, and $S$. pectinata found at higher elevations relative to the tidal frame, and S. alterniflora found at lower elevations. The trends observed here have been reflected in previous studies, with researchers theorizing that field germination likely depends on rainwater diluting the salt concentrations (Ungar 1978; Shumway and Bertness 1992; Fenner and Thompson 2005; Hanslin and Eggen 2005).

\section{CONCLUSION}

For the majority of species examined, germination increased when species were stored in conditions that reflected their natural environment. Therefore, for Atlantic Canada we recommend that species found in wet habitats should be stored in freshwater at $4{ }^{\circ} \mathrm{C}$ and species found in dry habitats should be stored dry at $4{ }^{\circ} \mathrm{C}$. As we saw with $\mathrm{O}$. biennis, however, species will not always fit this trend. There is still a need to test optimal germination conditions for vegetation in this region. Finally, note that only 9 species had a germination rate greater than $50 \%$. This could be attributable to a preference for vegetative reproduction, or because of a preference for a germination treatment not examined in this study. To address this, future work should examine how light, temperature variation, and storage duration affect the germination of these species.

\section{ACKNOWLEDGMENTS}

We thank Erinn O'Toole and Tony Bowron for their assistance with this study. Funding for this project was provided by Chiba University SEEDS Fund (Chiba University Open Recruitment for International Exchange Program), CB Wetland and Environmental Specialists, and the Natural Sciences and Engineering Research Council of Canada through a Discovery Grant and a Vanier Canada Graduate Scholarship.

\section{REFERENCES}

[ACCDC] Atlantic Canada Conservation Data Centre. 2017. Rarity ranks and legal status by province. URL: http://accdc.com/en/ ranks.html (accessed 6 Apr 2018).

Arnold S. 1972. Interactions of light and temperature on the germination of Plantago maritima L. New Phytologist 72:583-593.

Baskin CC, Baskin JM. 1994. Germination requirements of Oenothera biennis seeds during burial under natural seasonal temperature cycles. Canadian Journal of Botany 72:779-782.

Baskin CC, Baskin JM. 1995. Warm plus cold stratification requirement for dormancy break in seeds of the woodland herb Cardamine concatenata (Brassicaceae), and evolutionary implications. Canadian Journal of Botany 73:608-612.

Baskin C, Baskin JM. 2014. Seeds: ecology, biogeography, and evolution of dormancy and germination. 2nd ed. San Diego (CA): Elsevier/AP. 1586 p.

Bell JNB, Tallis JH. 1973. Empetrum nigrum L. Journal of Ecology 61:289305.

Biber P, Caldwell JD, Caldwell SR, Marenberg M. 2013a. Saltmeadow cordgrass Spartina patens: propagation guide. URL: https://docs. google.com/viewer?a=v\&pid=sites\&srcid=ZGVmYXVsdGRvbWFp bnxjb2FzdGFscGxhbnRyZXN0b3JhdGIvbnxneDozNWQ0MmM2 MmlzMmlwNmE0 (accessed 6 Apr 2018). University of Southern Mississippi.

Biber P, Caldwell JD, Caldwell SR, Marenberg M. 2013b. Smooth cordgrass Spartina alterniflora: propagation guide. URL: https://docs. google.com/viewer?a=v\&pid=sites\&srcid=ZGVmYXVsdGRvbWFp bnxjb2FzdGFscGxhbnRyZXN0b3JhdGlvbnxneDoxYjc4YzAxMGYw YThiODVm (accessed 6 Apr 2018). University of Southern Mississippi.

Bruno JF. 2000. Facilitation of cobble beach plant communities through habitat modification by Spartina alterniflora. Ecology 81:1179-1192.

Brzuszek RF, Richard LH, Susan JM. 2007. Landscape architects' use of native plants in the southeastern United States. HortTechnology 17:78-81.

Callaway J, Josselyn C. 1992. The introduction and spread of smooth cordgrass (Spartina alterniflora) in South San Francisco Bay. Estuaries 15:218-226.

Charpentier A, Mesléard F, Grillas P. 1998. The role of water level and salinity in the regulation of Juncus gerardi populations in former ricefields in southern France. Journal of Vegetation Science 9:361370 . 
Chinnasamy G, Bal AK. 2003. The pattern of seed development and maturation in beach pea (Lathyrus maritimus). Canadian Journal of Botany 81:531-540.

Chung C, Zhuo R, Xu G. 2004. Creation of Spartina plantations for reclaiming Dongtai, China, tidal flats and offshore sands. Ecological Engineering 23:135-150.

Clevering OA. 1995. Germination and seedling emergence of Scirpus lacustris L. and Scirpus maritimus L. with special reference to the restoration of wetlands. Aquatic Botany 50:63-78.

Coladonato M. 1992. Gaylussacia dumosa. URL: https://www.fs.fed. us/database/feis/plants/shrub/gaydum/all.html (accessed $6 \mathrm{Apr}$ 2018). Fire effects information system, U.S. Department of Agriculture, Forest Service, Rocky Mountain Research Station, Fire Sciences Laboratory.

Crossland DR, Vander Kloet SP. 1996. Berry consumption by the American Robin (Turdus migratorius) and the subsequent effect on seed germination, plant vigor, and dispersal of Vaccinium angustifolium. Canadian Field-Naturalist 110:303-309.

Dupuis SM. 1988. Autecology of Empetrum nigrum and Empetrum eamesii on the Avalon Peninsula, Newfoundland [MSc Thesis]. St. John's (NL): Department of Biology, Memorial University of Newfoundland. 43-48 p.

Fang X, Subudhi P, Venuto B, Harrison S, Ryan A. 2004. Influence of flowering phenology on seed production in smooth cordgrass (Spartina alterniflora Loisel.). Aquatic Botany 80:139-151.

Fenner M, Thompson K. 2005. The ecology of seeds. Cambridge (UK): Cambridge University Press. 260 p.

Flessner TR, Trindle J. 2003. Propagation protocol for production of Anaphalis margaritacea (L.) Benth. seeds (seed from seed increase). URL: https://www.nrcs.usda.gov/Internet/FSE_PLANTMATERIALS/ publications/orpmcmt9963.pdf (accessed 6 Apr 2018). USDA NRCS, Corvallis Plant Materials Center, Corvallis, Oregon, and University of Idaho, College of Natural Resources, Forest Research Nursery.

Government Canada. 2018. Canadian climate normals, 1981-2010 station data. URL: http://climate.weather.gc.ca/climate_normals/ index_e.html (accessed 20 Aug 2018). Canadian Department of Environment and Natural Resources, Halifax, Nova Scotia, Canada.

Hanslin HM, Eggen T. 2005. Salinity tolerance during germination of seashore halophytes and salt-tolerant grass cultivars. Seed Science Research 15:43-50.

Heim A, Appleby-Jones S, Lundholm J. 2016. Green roof thermal and stormwater performance comparisons between native and industry-standard plant species. Cities and the Environment 9: $1-15$.

Ignaciuk R, Lee JA. 1980. The germination of four annual strand-line species. New Phytologist 84:581-591.

Kartesz JT, Meacham CA. 1999. Synthesis of the North American flora, Version 1.0. Chapel Hill (NC): North Carolina Botanical Garden.

Kearns V, Toole EH. 1939. Temperature and other factors affecting the germination of fescue seed. Technical Bulletin No. 638. URL: https://naldc.nal.usda.gov/download/CAT86200633/PDF (accessed 6 Apr 2018). Washington (DC): USDA, Division of Seed Investigations, Bureau of Plant Industry.

Li R, Shi F, Fukuda K. 2010. Interactive effects of salt and alkali stresses on seed germination, germination recovery, and seedling growth of a halophyte Spartina alterniflora (Poaceae). South African Journal of Botany 76:380-387.

Liu K, Baskin JM, Baskin CC, Bu H, Liu M, Liu W, Du G. 2011. Effect of storage conditions on germination of seeds of 489 species from high elevation grasslands of the eastern Tibet Plateau and some implications for climate change. American Journal of Botany 98:12-19.

Maclvor JS, Lundholm JT. 2011. Performance evaluation of native plants suited to extensive green roof conditions in a maritime climate. Ecological Engineering 37:407-417.

Mobberley D. 1956. Taxonomy and distribution of the genus Spartina. lowa State College Journal of Science 30:471-574.

Moore LM, Anderson MK. 2002. Plant guide: New York aster Symphyotrichum novi-belgii (L.) Nesom var. novi-belgii. URL: https://plants. usda.gov/plantguide/pdf/cs_synon.pdf (accessed 6 Apr 2018). USDA Natural Resources Conservation Service.

Mooring MT, Cooper AW, Seneca ED. 1971. Seed germination response and evidence for height ecophenes in Spartina alterniflora from North Carolina. American Journal of Botany 58:48-55.

Nellis DW. 1994. Seashore plants of South Florida and the Caribbean. Sarasota (FI): Pineapple Press. 164 p.

Orava C, Drake D. 1997. Effects of salinity on germination and growth of Solidago sempervirens var. mexicana (L.) Fern. Castanea 62:272277.

Pereira MJ, Mourato C. 2012. Effects of bird ingestion on seed germination of Vaccinium cylindraceum (Ericaceae), an endemic species of the Azores archipelago. Botany 90:373-377.

Porter C, Lundholm J, Bowron T, Lemieux B, Van Proosdij D, Neatt N, Graham J. 2015. Classification and environmental correlates of tidal wetland vegetation in Nova Scotia, Canada. Botany 93:825-841.

Roland AE, Zinck M. 1998. Roland's flora of Nova Scotia. 3rd ed. Halifax (NS): Nimbus Publishing. 1300 p.

Seneca ED. 1974. Germination and seedling response of Atlantic and Gulf Coasts populations of Spartina alterniflora. American Journal of Botany 61:947-956.

Shumway SW, Bertness MD. 1992. Salt stress limitation of seedling recruitment in a salt marsh plant community. Oecologia 92:490-497.

Ungar IA. 1978. Halophyte seed germination. Botanical Review 44:233-264.

[USDA NRCS] USDA Natural Resources Conservation Service. 2018. The PLANTS database. URL: http://plants.usda.gov (accessed 6 Apr 2018). Greensboro (NC): National Plant Data Team.

Vander Kloet SP, Hill NM. 2000. Bacca quo vadis: regeneration niche differences among 7 sympatric Vaccinia. Seed Science Research 10:89-97.

Warton DI, Hui FK. 2011. The arcsine is asinine: the analysis of proportions in ecology. Ecology 92:3-10. 
APPENDIX TABLES

Table A.1

Habitats where each species used in this study is commonly found.

\begin{tabular}{|c|c|c|}
\hline Species & Family & Habitat \\
\hline Anaphalis margaritacea (L.) Benth. & Asteraceae & Roadside \\
\hline Atriplex glabriusculata Edmondston & Chenopodiaceae & Salt marsh \\
\hline Calamagrostis pickeringii A. Gray & Poaceae & Coastal barren \\
\hline Empetrum nigrum L. & Ericaceae & Coastal barren \\
\hline Empetrum eamesii Fernald \& Wiegand & Ericaceae & Coastal barren \\
\hline Festuca rubra L. & Poaceae & Coastal barren \\
\hline Gaylussacia dumosa Fern. & Ericaceae & Coastal barren \\
\hline Hudsonia ericoides L. & Cistaceae & Coastal barren \\
\hline Juncus gerardii Loisel. & Juncaceae & Salt marsh \\
\hline Lathyrus japonicus Willd. & Fabaceae & Salt marsh, dunes \\
\hline Limonium carolinianum (Walter) Britton & Plumbaginaceae & Salt marsh \\
\hline Oenothera biennis L. & Onagraceae & Roadside \\
\hline Plantago maritima L. & Plantaginaceae & Salt marsh, coastal barren \\
\hline Schoenoplectus maritimus (L.) Nels. & Cyperaceae & Salt marsh \\
\hline Solidago sempervirens L. & Asteraceae & Salt marsh, dunes, coastal barren \\
\hline Spartina alterniflora Loisel. & Poaceae & Salt marsh \\
\hline Spartina patens (Ait.) Muhl. & Poaceae & Salt marsh \\
\hline Spartina pectinata Bosc ex Link & Poaceae & Salt marsh \\
\hline Symphyotrichum novi-belgii L. & Asteraceae & Coastal barren, roadside \\
\hline Vaccinium angustifolium Ait. & Ericaceae & Coastal barren \\
\hline Vaccinium macrocarpon Ait. & Ericaceae & Coastal barren \\
\hline
\end{tabular}

TABLE A.2

For each trial, this table includes the number of replicates used for each treatment, the number of seeds used in each replicate, and the location in Nova Scotia where seeds were collected.

\begin{tabular}{llcl} 
Trial & Replicates for each treatment & Seeds per replicate & Location of seed collection \\
\hline $\mathbf{1}$ & 18, Vaccinium macrocarpon & 16 & $44.50722 \mathrm{~N}, 63.52278 \mathrm{~W}$ \\
& 18, Empetrum nigrum & 8 & $44.50722 \mathrm{~N}, 63.52278 \mathrm{~W}$ \\
& 18, Empetrum eamesii & 8 & $44.50722 \mathrm{~N}, 63.52278 \mathrm{~W}$ \\
& 18, Vaccinium angustifolium & 41 & $44.50722 \mathrm{~N}, 63.52278 \mathrm{~W}$ \\
& 9, Gaylussacia dumosa & 10 & $44.50722 \mathrm{~N}, 63.52278 \mathrm{~W}$ \\
\hline $\mathbf{2}$ & 3 & 20 & $44.50722 \mathrm{~N}, 63.52278 \mathrm{~W}$ \\
& & & $44.63222 \mathrm{~N}, 63.58139 \mathrm{~W}$ \\
\hline $\mathbf{3}$ & 8 & 20 & $44.64556 \mathrm{~N}, 63.37444 \mathrm{~W}$ \\
& & & $44.64556 \mathrm{~N}, 63.37444 \mathrm{~W} 44.64972 \mathrm{~N}, 63.42083 \mathrm{~W}$ \\
& & & $45.07822 \mathrm{~N}, 64.14306 \mathrm{~W}$ \\
$\mathbf{4}$ & 3 & 50 & $44.50722 \mathrm{~N}, 63.52278 \mathrm{~W}$ \\
& & & $44.64556 \mathrm{~N}, 63.37444 \mathrm{~W}$ \\
\hline
\end{tabular}

Notes: For Trial 1, the number of seeds for each replicate was chosen based on the average number of seeds found in a typical berry for that species. 
TABLE A.3

Trial 1: Two-way ANOVA table for the germination rate of E. nigrum, E. eamesii,

$\mathrm{V}$. angustifolium, and V. macrocarpon for seeds and berries stored at $4{ }^{\circ} \mathrm{C}$ and $-20^{\circ} \mathrm{C}$.

\begin{tabular}{|c|c|c|c|c|c|}
\hline Species & Df & Sum sq & Mean sq & Fvalue & $\operatorname{Pr}(>\mathrm{F})$ \\
\hline \multicolumn{6}{|c|}{ Vaccinium angustifolium } \\
\hline Fruit & 1 & 981.6 & 981.6 & 45.44 & $4.14 \mathrm{e}-09$ \\
\hline Temp & 1 & 981.6 & 981.6 & 45.44 & $4.14 \mathrm{e}-09$ \\
\hline Fruit : Temp & 1 & 981.6 & 981.6 & 45.44 & $4.14 \mathrm{e}-09$ \\
\hline Residuals & 68 & 1469.0 & 21.6 & & \\
\hline \multicolumn{6}{|c|}{ Empetrum nigrum } \\
\hline Fruit & 1 & 2813 & 2812 & 18.03 & $6.76 \mathrm{e}-05$ \\
\hline Temp & 1 & 3134 & 3134 & 20.09 & $2.91 \mathrm{e}-05$ \\
\hline Fruit : Temp & 1 & 2812 & 2812 & 18.03 & $6.76 \mathrm{e}-05$ \\
\hline Residuals & 68 & 10608 & 156 & & \\
\hline \multicolumn{6}{|c|}{ Empetrum eamesii } \\
\hline Fruit & 1 & 957 & 957.0 & 12.81 & 0.00064 \\
\hline Temp & 1 & 957 & 957.0 & 12.81 & 0.00064 \\
\hline Fruit: Temp & 1 & 957 & 957.0 & 12.81 & 0.00064 \\
\hline Residuals & 68 & 5078 & 74.7 & & \\
\hline \multicolumn{6}{|c|}{ Vaccinium macrocarpon } \\
\hline Fruit & 1 & 35548 & 35548 & 128.4 & $4.32 \mathrm{e}-13$ \\
\hline Residuals & 34 & 9412 & 277 & & \\
\hline
\end{tabular}

Notes: For V. macrocarpon, seeds and berries were stored only at $4{ }^{\circ} \mathrm{C}$.

\section{TABLE A.4}

\begin{tabular}{|c|c|c|c|c|c|c|}
\hline Germination rate & Trans. & Df & Sum sq & Mean sq & $F$ value & $\operatorname{Pr}(>\mathrm{F})$ \\
\hline Anaphalis margaritacea & & 1 & 2.338 & 2.3378 & 3.078 & 0.154 \\
\hline Residuals & & 4 & 3.038 & 0.7595 & & \\
\hline Atriplex glabriusculata & & 1 & 7.709 & 7.709 & 12.2 & 0.0251 \\
\hline Residuals & & 4 & 2.528 & 0.632 & & \\
\hline Festuca rubra & $\log$ & 1 & 0.01147 & 0.011473 & 1.861 & 0.244 \\
\hline Residuals & & 4 & 0.02466 & 0.006165 & & \\
\hline Limonium carolinianum & & 1 & 0.6616 & 0.6616 & 2.995 & 0.159 \\
\hline Residuals & & 4 & 0.8838 & 0.2209 & & \\
\hline Lathyrus japonicus & & 1 & 0.2071 & 0.2071 & 1 & 0.374 \\
\hline Residuals & & 4 & 0.8283 & 0.2071 & & \\
\hline Symphyotrichum novi-belgii & & 1 & 0.557 & 0.5570 & 1.1 & 0.353 \\
\hline Residuals & & 4 & 2.026 & 0.5064 & & \\
\hline Oenothera biennis & $\log$ & 1 & 5.325 & 5.325 & 85.86 & 0.000754 \\
\hline Residuals & & 4 & 0.248 & 0.062 & & \\
\hline Spartina alterniflora & & 1 & 1.1170 & 1.1170 & 9.219 & 0.0385 \\
\hline Residuals & & 4 & 0.4847 & 0.1212 & & \\
\hline
\end{tabular}


TABLE A.4 (continued)

One-way ANOVA tables for the average germination rate for species in Trial 2.

\begin{tabular}{lcccccc} 
Germination rate & Trans. & Df & Sum sq & Mean sq & Fvalue & $\operatorname{Pr}(>\mathbf{F})$ \\
\hline Plantago maritima & Log & 1 & 5.881 & 5.881 & 204.3 & 0.000139 \\
$\quad$ Residuals & & 4 & 0.115 & 0.029 & & 0.929 \\
Schoenoplectus maritimus & & 1 & 0.014 & 0.0144 & 0.009 & \\
$\quad$ Residuals & 4 & 6.450 & 1.6124 & & 0.00404 \\
Spartina patens & 1 & 4.629 & 4.629 & 35.23 & 0.00739 \\
$\quad$ Residuals & 4 & 0.526 & 0.131 & & 0.0461 \\
Spartina pectinata & 1 & 7.667 & 7.667 & 25.19 & \\
$\quad$ Residuals & 4 & 1.218 & 0.304 & & 8.153 & 0 \\
Solidago sempervirens & 1 & 9.654 & 9.654 & &
\end{tabular}

Notes: Each species was stored at $4{ }^{\circ} \mathrm{C}$ and had a freshwater and dry storage treatment. Non-normal data sets were log transformed (Trans.).

TABLE A.5

One-way ANOVA tables for average number of days until germination for species in Trial 2.

\begin{tabular}{|c|c|c|c|c|c|c|}
\hline Average days until germination & Trans. & Df & Sum sq & Mean sq & Fvalue & $\operatorname{Pr}(>\mathrm{F})$ \\
\hline Atriplex glabriusculata & & 1 & 827.2 & 827.2 & 40.42 & 0.00314 \\
\hline Residuals & & 4 & 81.9 & 20.5 & & \\
\hline Anaphalis margaritacea & & 1 & 2.341 & 2.3408 & 4.155 & 0.178 \\
\hline Residuals & & 2 & 1.127 & 0.5633 & & \\
\hline Festuca rubra & & 1 & 19.512 & 19.512 & 71.82 & 0.00106 \\
\hline Residuals & & 4 & 1.087 & 0.272 & & \\
\hline Limonium carolinianum & $\log$ & 1 & 2.235 & 2.235 & 146.5 & 0.000267 \\
\hline Residuals & & 4 & 0.061 & 0.0153 & & \\
\hline Lathyrus japonicus & & 1 & 6.0 & 6.0 & 1.0 & 0.374 \\
\hline Residuals & & 4 & 24 & 6.0 & & \\
\hline Symphyotrichum novi-belgii & & 1 & 295.68 & 295.68 & 17.66 & 0.0137 \\
\hline Residuals & & 4 & 66.98 & 16.74 & & \\
\hline Oenothera biennis & & 1 & 1872.7 & 1872.7 & 92.86 & 0.000649 \\
\hline Residuals & & 4 & 80.7 & 20.2 & & \\
\hline Plantago maritima & $\log$ & 1 & 1.443 & 1.4431 & 4.675 & 0.0967 \\
\hline Residuals & & 4 & 1.235 & 0.3087 & & \\
\hline Spartina alterniflora & & 1 & 227.55 & 227.55 & 13.21 & 0.0221 \\
\hline Residuals & & 4 & 68.89 & 17.22 & & \\
\hline Schoenoplectus maritimus & & 1 & 50.58 & 50.58 & 0.947 & 0.386 \\
\hline Residuals & & 4 & 213.57 & 53.39 & & \\
\hline Spartina patens & & 1 & 3361 & 3361 & 39.41 & 0.00329 \\
\hline Residuals & & 4 & 341.0 & 85.0 & & \\
\hline Spartina pectinata & & 1 & 2150.8 & 2150.8 & 54.06 & 0.00182 \\
\hline Residuals & & 4 & 159.1 & 39.8 & & \\
\hline Solidago sempervirens & & 1 & 57.47 & 57.47 & 31.07 & 0.00508 \\
\hline Residuals & & 4 & 7.40 & 1.85 & & \\
\hline
\end{tabular}

Notes: Each species was stored at $4{ }^{\circ} \mathrm{C}$ and had a freshwater and dry storage treatment. Non-normal data sets were log transformed (Trans.). 
TABLE A.6

ANOVA table for the germination rate for S. alterniflora, S. patens, and S. pectinata when stored in freshwater (fresh) vs. saltwater (salt) at $4{ }^{\circ} \mathrm{C}$ vs. $-20^{\circ} \mathrm{C}$.

\begin{tabular}{|c|c|c|c|c|c|c|}
\hline & Trans. & Df & Sum sq & Mean sq & $F$ value & $\operatorname{Pr}(>\mathrm{F})$ \\
\hline Spartina alterniflora & $\log (1+$ data $)$ & & & & & \\
\hline Temperature & & 1 & 63.5 & 63.5 & 59.617 & $1.47 \mathrm{e}-10$ \\
\hline Irrigation & & 1 & .53 & .53 & .495 & .484 \\
\hline Temp : irrigation & & 1 & 1.38 & 1.38 & 1.295 & .260 \\
\hline Residuals & & 60 & 63.91 & 1.07 & & \\
\hline Spartina patens & sqrt & & & & & \\
\hline Temperature & & 1 & 141.49 & 141.49 & 27.964 & $1.83 \mathrm{e}-06$ \\
\hline Irrigation & & 1 & 16.01 & 16.01 & 3.164 & 0.08033 \\
\hline Temp : irrigation & & 1 & 59.6 & 59.6 & 11.779 & 0.00109 \\
\hline Residuals & & 60 & 303.59 & 5.06 & & \\
\hline Spartina pectinata & $\wedge(1 / 3)$ & & & & & \\
\hline Temperature & & 1 & 23.36 & 23.36 & 22.24 & $1.48 \mathrm{e}-05$ \\
\hline Irrigation & & 1 & 11.82 & 11.82 & 11.26 & .00138 \\
\hline Temp : irrigation & & 1 & 19.65 & 19.66 & 18.71 & $5.84 \mathrm{e}-05$ \\
\hline Residuals & & 60 & 63.03 & 1.05 & & \\
\hline
\end{tabular}

\section{TABLE A.7}

Two-way ANOVA table for the average number of days until germination for S. alterniflora, S. patens, and S. pectinata when stored in freshwater (fresh) vs. saltwater (salt) at $4{ }^{\circ} \mathrm{C}$ vs. $-20^{\circ} \mathrm{C}$.

\begin{tabular}{|c|c|c|c|c|c|c|}
\hline & Trans. & Df & Sum sq & Mean sq & Fvalue & $\operatorname{Pr}(>\mathrm{F})$ \\
\hline \multicolumn{7}{|l|}{ Spartina alterniflora } \\
\hline Temperature & & 1 & 47.27 & 47.27 & 3.539 & .07388 \\
\hline Irrigation & & 1 & 118.23 & 118.23 & 8.851 & 0.00722 \\
\hline Residuals & & 21 & 280.52 & 13.36 & & \\
\hline Spartina patens & $\log$ & & & & & \\
\hline Temperature & & 1 & 0.2982 & 0.2982 & 5.207 & 0.027392 \\
\hline Irrigation & & 1 & 1.0247 & 1.0247 & 17.894 & 0.000116 \\
\hline Temp: irrigation & & 1 & 0.0842 & 1.470 & 0.231782 & \\
\hline Residuals & & 44 & 442.5198 & 0.0573 & & \\
\hline Spartina pectinata & sqrt & & & & & \\
\hline Temperature & & 1 & 14.290 & 14.290 & 76.380 & $6.55 e-11$ \\
\hline Irrigation & & 1 & 4.373 & 4.373 & 23.373 & $1.91 \mathrm{e}-05$ \\
\hline Temp: irrigation & & 1 & 1.868 & 1.868 & 9.982 & 0.00297 \\
\hline Residuals & & 41 & 7.671 & 0.187 & & \\
\hline
\end{tabular}


One-way ANOVA tables for the average germination rate and average number of days until germination for species in Trial 4.

\begin{tabular}{|c|c|c|c|c|c|}
\hline Germination rate & Df & Sum sq & Mean sq & $F$ value & $\operatorname{Pr}(>\mathrm{F})$ \\
\hline Hudsonia ericoides & 1 & 0.9176 & 0.9176 & 3.499 & 0.135 \\
\hline Residuals & 4 & 1.0491 & 0.2623 & & \\
\hline Limonium carolinianum & 1 & 3.060 & 3.060 & 11.38 & 0.028 \\
\hline Residuals & 4 & 1.076 & 0.269 & & \\
\hline Days until germination & Df & Sum sq & Mean sq & Fvalue & $\operatorname{Pr}(>\mathrm{F})$ \\
\hline Hudsonia ericoides & 1 & 6.380 & 6.380 & 1.812 & 0.311 \\
\hline Residuals & 2 & 7.042 & 3.521 & & \\
\hline Limonium carolinianum & 1 & 570.2 & 570.2 & 91.17 & 0.00067 \\
\hline Residuals & 4 & 25.0 & 6.3 & & \\
\hline
\end{tabular}

Notes: Each species was stored at $4{ }^{\circ} \mathrm{C}$ and had a freshwater and a dry storage treatment.

TABLE A.9

Two-way ANOVA test for the average germination rate of Plantago maritima in Trial 4.

\begin{tabular}{lccccc} 
& Df & Sum sq & Mean sq & Fvalue & $\operatorname{Pr}(>\mathrm{F})$ \\
\hline Storage & 1 & 507.0 & 507.0 & 7.383 & 0.02636 \\
\hline Irrigation & 1 & 867.0 & 867.0 & 12.626 & 0.00747 \\
\hline Storage : Irrigation & 1 & 800.3 & 800.3 & 11.655 & 0.00917 \\
\hline Residuals & 8 & 549.3 & 68.7 & & \\
\hline
\end{tabular}

Notes: Treatments included freshwater vs. dry storage and the use of saltwater vs. freshwater irrigation during germination.
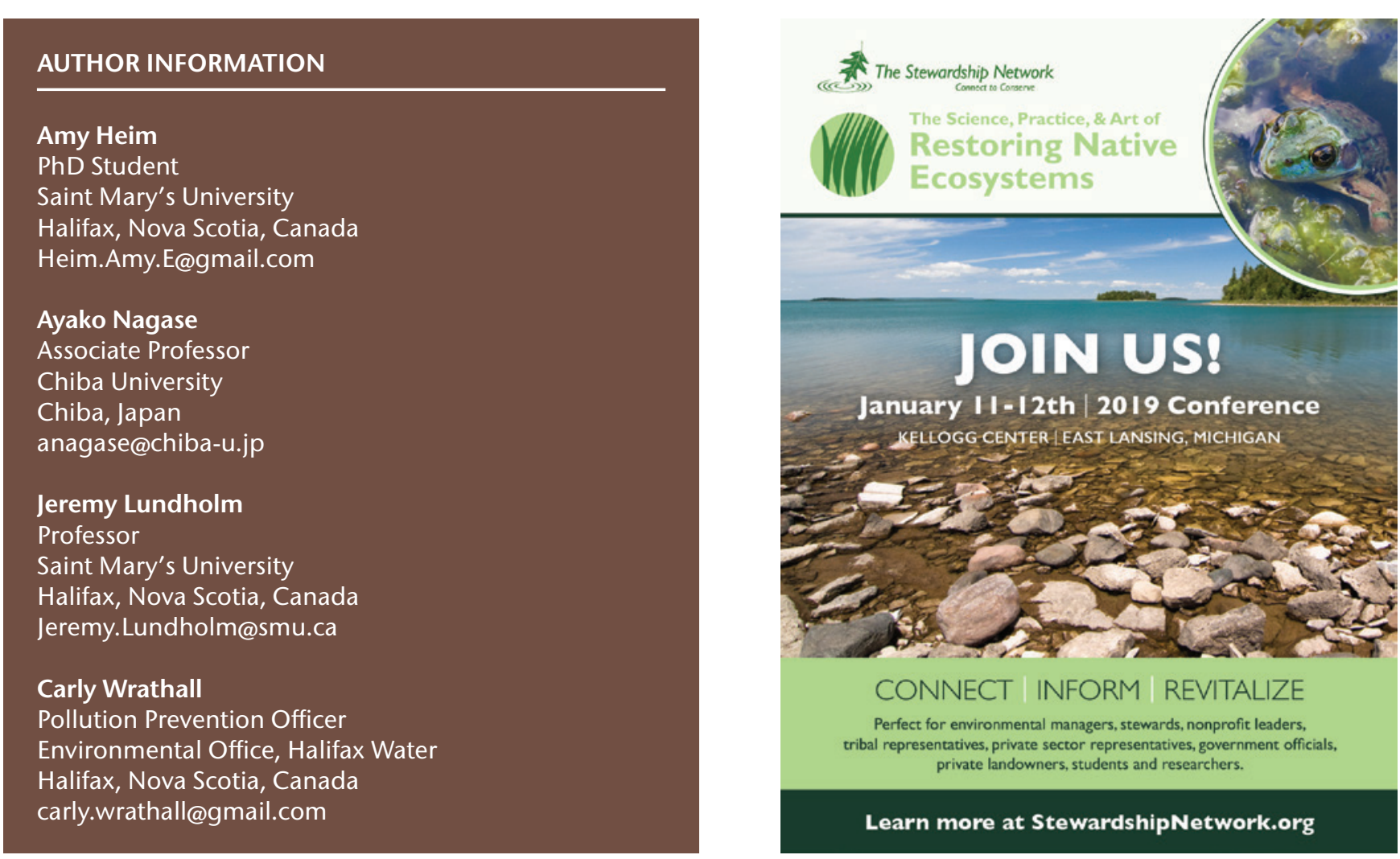